\title{
Paisagens AFrodiaspóricas em Diário de UM RETORNO AO PAÍS NATAL, DE AIMÉ CÉSAIRE
}

Michel Mingote Ferreira de ÁZARA*

\section{RESUMo}

O objetivo deste artigo foi investigar em Diário de um retorno ao país natal (2012), poema fundamental do poeta martiniquenho Aimé Césaire, a configuração das paisagens afrodiaspóricas. O longo poema, escrito em estilo livre, é um dos marcos do movimento político, estético, cultural e ideológico da negritude, lançado em Paris, na década de 1930, mas que aglutina em seu bojo diversas manifestações culturais da Diáspora Negra, tais como o Renascimento Harlem, surgido nos Estados Unidos, nos anos de 1920, o indigenismo da literatura Haitiana, da mesma década, e o negrismo cubano dos anos de 1930.

Palavras-chave: Negritude. Aimé Césaire. Diáspora Negra. Paisagens. Poética do desabrigo.

\section{INTRODUÇÃO}

"No fim da madrugada, sobre essa tão frágil espessura de terra ultrapassada de modo humilhante por seu grandioso porvir - os vulcões explodirão, a água nua levará as manchas maduras do sol e só restará um morno fervilhar picado por aves marinha - a praia dos sonhos e o insensato despertar." (CÉSAIRE, 2012, p. 9)

Obra seminal na poética de Aimé Césaire, o Diário de um retorno ao país natal (2012) teve a sua primeira publicação na revista francesa Volontés em 1939. Ele consagra a primeira aparição, em um poema, do termo

Pós-doutorando em Literatura Comparada na Universidade de São Paulo/USP, São Paulo, São Paulo, Brasil. Bolsista Fapesp (processo n 2018/13100-7).

E-mail: michel_mingote@yahoo.com.br. OrcidiD: https://orcid.org/0000-0002-9904-9781 
negritude, movimento que aglutina em seu bojo as diversas manifestações estéticas, culturais e ideológicas da Diáspora Negra nas Américas, como o indigenismo haitiano, o Renascimento do Harlem e o negrismo cubano. Sendo a questão da negritude e da memória afrodiaspórica centrais para a compreensão do poema, investigamos como esses tópicos se relacionam com o tema da nossa abordagem, a configuração das paisagens afrodiaspóricas em Diário de um retorno ao país natal.

Fundada pelo ato inaugural do poeta italiano Petrarca ao subir o Monte Ventor em 1336, a concepção moderna e ocidental da paisagem pressupõe, inicialmente, um olhar soberano que engloba a porção do espaço que se oferece ao olhar do sujeito. Tal ato marca também a entrada do homem na história, a secularização do olhar, e a passagem do sagrado ao profano.

A constituição da paisagem coincide de fato com a ocupação de um elevado, a palavra entendida tanto no sentido físico quanto no sentido simbólico e transcendental. Petrarca legou um documento excepcional deste ato fundador na sua carta do Monte Ventor [...] A montanha funciona neste "primeiro homem moderno" (Jakob Burckhardt) como a plataforma de uma elevação, e aqui sobre vários planos. $\mathrm{O}$ novo homem se destaca por uma transgressão consciente da imposição normativa da Teologia (à época, da explicação do mundo em geral) e do sentido comum (simbolizado pela figura de um velho camponês). Ele ultrapassa as regras do plano - insípido, que é imposto - se elevando por sua própria força e sua própria vontade no elevado sobre o qual ele exercerá um novo olhar $[. . .]^{1}$ (JAKOB, 2013, p. 37, tradução nossa).

La constitution du paysage coïncide en effet avec l'occupation d'une hauteur, le mot entendu aussi bien au sens physique que symbolique et transcendantale. Pétrarque a légué un document exceptionnel de cet acte fondateur dans sa lettre dite du Mont Ventoux. [...] La montagne fonctionne chez ce "premier homme moderne" (Jakob Burckhardt) comme la plateforme d'une élévation, et ceci sur plusieurs plans. L'homme nouveau s'est détache à travers une transgression consciente du diktat normatif de la théologie (à l'époque, de l'explication du monde en général) et du sens commun (symbolisé par la figure d'un ancien berger). Il dépasse les règles de la plaine - et plate, imposée -, s'élevant de sa propre force et de sa propre volonté en haut où il exercera un nouveau regard $[\ldots]$. 
Apesar da ambiguidade e complexidade deste ato primevo do poeta italiano, e também das diversas implicações que envolvem o conceito moderno e ocidental da paisagem, por nós analisado em outro momento ${ }^{2}$, ressaltamos que a concepção clássica da paisagem, dada na tradição europeia pelo primado da visão e pelo viés da perspectiva, envolve sempre um sujeito que observa determinado espaço desde um monte ou elevado. Um caso emblemático desse tipo de percepção do espaço é o quadro clássico do pintor romântico alemão Caspar David Friedrich, de 1818, intitulado Um viajante sobre mar de nuvens, em que "o caminhante, cuja estatura se iguala à das montanhas, parece dominar o mar de névoas que se estende aos seus pés"3 (COLLOT, 2011, p. 92, tradução nossa).

As grandes navegações que conectaram o Ocidente às Américas a partir do final do século XV abriram o olhar europeu para novas paisagens, apreendidas como pitorescas por parte dos viajantes que aqui aportavam. Como bem analisou Süssekind (2000), o que se observa nos relatos de viagem dos naturalistas europeus era uma necessidade de catalogar, classificar e inventariar tudo aquilo que se oferecia ao olhar. Mas as diversas percepções e projeções dos viajantes já começava na proa do navio, no mar aberto que se oferecia aos seus olhares. Nesse período de expansão mercantil alimentada pelo tráfico negreiro, que engloba os séculos XV, XVI, XVII, XVIII e XIX, um outro tipo de viagem acontecia no bojo dos navios, no corpo, na língua, nas crenças e na mente dos africanos escravizados e deportados às Américas.

\section{A BARCA ABERTA}

À imagem do mar aberto disponível ao olhar do contemplador durante a travessia do Atlântico se contrapõe à imagem do bojo do navio negreiro, um ventre que acolhe em seu interior todas as crispações, medos,

2 Cf. ÁZARA, 2015.

3 "le promeneur, dont la stature s'égale à celle des montagnes, semble dominer la mer des nuages qui s'étend à ses pieds". 
delírios, putrefações daqueles que estavam sendo deportados. No espaço exíguo e fechado do navio negreiro, o direito de olhar para o exterior era negado. Dessa forma, não existia paisagem possível para os sujeitos que foram escravizados. No entanto, como bem salientou Glissant (2011), o abismo do ventre do navio, o abismo do fundo do oceano que recebia os corpos daqueles que adoeciam ou faleciam durante a travessia, também comportava o abismo do desconhecido, a gestação de novas subjetividades que seriam reinventadas em solo americano, através dos rastros/resíduos de memórias, tradições, línguas e ancestralidades. Dessa forma, ainda nas palavras do escritor martiniquenho, o ventre do navio é um poço-matriz, que gerará todas as transformações e crioulizações porvir:

O primeiro é um terror inaugural, quando mergulhas no ventre da barca. Uma barca, segundo a tua poética, não tem ventre, uma barca não engole, não devora, uma barca pilota-se a céu aberto. $O$ ventre dessa barca dissolve-te, precipita-se num não mundo onde gritas. Essa barca é uma matriz, poço-matriz [...] A experiência do abismo está no abismo e fora dele. Tormento daqueles que nunca saíram do abismo: que passaram diretamente do ventre do navio negreiro para o ventre violeta dos fundos do mar. Mas a sua provação não morreu, vivificou-se nesse contínuo-descontínuo: o pânico do país novo, a saudade da terra perdida, e por fim a aliança com a terra imposta, sofrida, redimida. A memória não sabida do abismo serviu de lodo para essas metamorfoses. (GLISSANT, 2011, p. 1-2)

Assim sendo, se a livre contemplação da paisagem era negada aos sujeitos escravizados, tanto na travessia transatlântica quanto na vida servil nas Américas, ao mesmo tempo, o abismo do desconhecido, referido por Glissant, descortinava a produção de novas formas de subjetividade, processos imprevisíveis de crioulização, de mestiçagem, de simbiose entre diversos elementos culturais em um mesmo solo. Nas palavras de Mortari (2015, p. 56), a "diáspora não é apenas sinônimo da imigração à força, mas também uma redefinição identitária, ou seja, a construção de novas formas de ser, agir e pensar no mundo". A partir do pensamento 
do rastro/resíduo, novas formas de existir e resistir foram sendo moldadas na diáspora negra. É o caso das línguas crioulas, dos sincretismos religiosos, das danças, cantos e hábitos. A leitura que propomos aqui é a de que todos esses elementos, além da quilombagem ${ }^{4}$, enquanto ato de resistência espacial e cultural, retornam para o olhar daquele que é considerado o livro fundador do movimento da negritude, o Diário de um retorno ao país natal, de Aimé Cesaire. Mesmo quando há um olhar direto em relação à paisagem, esse olhar só pode ser compreendido por esta cisão inicial que foi o movimento diaspórico, que implica um sujeito eternamente desabrigado, um Homeless (PEREIRA, 2017). Dessa forma, a paisagem da Diáspora negra será apreendida, sobretudo na obra do poeta martiniquenho, através de um olhar rizomático, em trânsito, em diálogo constante entre o aqui e o acolá. Assim como na primeira cisão ocorrida com o tráfico atlântico, momento o qual Mbembe (2019) nomeara de o primeiro momento da razão negra, no seu segundo momento, que teve início no final do século XVIII, “[...] por meio de seus próprios traços, os negros, esses seres capturados por outros, conseguiram articular uma linguagem própria, reivindicando o estatuto de sujeitos plenos no mundo dos vivos" (p.14), a mesma desterritorialização e desabrigo aparecem, agora no sujeito imigrante, que traz à tona, em sua escrita, os rastros/ resíduos do primeiro desamparo.

\section{PAISAgENS AFRODIASPÓRICAS}

Diário de um retorno ao país natal apresenta, através de um olhar transnacional, a consolidação do termo negritude, movimento políticoestético-cultural e ideológico. A tomada de consciência da condição do homem negro no mundo se dá, no poema, no instante em que o sujeito, distanciado da sua terra natal, a ilha da Martinica, território ultramarinho francês, volta o seu olhar ao seu local de origem, a partir da França metropolitana. O poema começa evocando o estado crepuscular

4 Cf. MOURA, 2019. 
do alvorecer, "[n]o fim da madrugada..." (CÉSAIRE, 2012, p. 9), estado propício a uma percepção sensível do espaço. Esta zona intervalar onde começa o poema favorece uma espécie de protopercepção, reino dos perceptos, das micropercepóes onde o sujeito se deixa contaminar por este ambiente vacilante, em que o próprio eu atinge esta zona crepuscular nele mesmo. $\mathrm{O}$ sujeito olha e é olhado pela paisagem, mas aqui, tal olhar não advém do contato direto com a paisagem, uma vez que o sujeito se encontra distante da sua ilha natal, mas pela memória. E é nesta hora, o fim da madrugada, espaço de devires e de visões, fonte matricial do próprio poema, que a paisagem da terra natal transborda no poema através de imagens e evocações gravadas no corpo do poeta. Dessa forma, a hora crepuscular, hora do nascimento do poema, é o momento de surgimento desta protopercepção que é o percepto

No seu todo indivisível, um percepto é, por assim dizer, uma protopercepção, visto que, a esse ato automático, não cabe, propriamente, a consciência, mas apenas o registro do receptor: uma percepção passiva, próxima a um hábito de perceber espontâneo e incontrolável, ao qual não corresponde crença ou descrença (FERRARA, 1993, p. 173).

Como bem formulou Deleuze e Guattari (1992), o percepto é a paisagem anterior ao homem, na ausência do homem, e remete aos devires e atravessamentos experimentados de maneira pré-conceitual e pré-reflexiva. É através da escrita que se atinge o percepto, que independe das percepções de um sujeito poético ou de um personagem:

A paisagem vê. Em geral, qual o grande escritor que não soube criar esses seres de sensação que conservam em si a hora de um dia, o grau do calor de um momento (as colinas de Faulkner, a estepe de Tolstoi ou a de Tchekov)? O percepto é a paisagem anterior ao homem, na ausência do homem. Mas em todos estes casos, por que dizer isso, já que a paisagem não é independente das supostas percepções dos personagens, e, por seu intermédio, das percepções e lembranças do autor? E como a cidade poderia ser sem homem ou antes dele, o espelho, sem a velha que nele se reflete, mesmo se ela não se mira nele? É o enig- 
ma (frequentemente comentado) de Cézanne: "o homem ausente, mas inteiro na paisagem”. [...] Os afetos são precisamente estes devires não humanos do homem, como os perceptos (entre eles a cidade) são as paisagens não humanas da natureza. "Há um minuto do mundo que passa”, não o conservaremos sem "nos transformarmos nele", diz Cézanne. Não estamos no mundo, tornamo-nos com o mundo, nós nos tornamos, contemplando-o. Tudo é visão, devir. Tornamo-nos universo. (DELEUZE; GUATTARI, 1992, p. 218-219).

O sujeito poético é atravessado por intensidades impessoais, ele se dessubjetiviza, ao afetar e ser afetado intensamente pela paisagem, ainda que pelo canal da memória. $\mathrm{O}$ texto se configura como um bloco de sensações. Ainda nas palavras de Deleuze e Guattari (1992, p. 213), as sensações, perceptos e afectos, são seres que valem por si mesmos e excedem qualquer vivido: "[e]xistem na ausência do homem, podemos dizer, porque o homem, tal como ele é fixado na pedra, sobre a tela ou ao longo das palavras, é ele próprio um composto de perceptos e de afectos. A obra de arte é um ser de sensação, e nada mais: ela existe em si” (DELEUZE; GUATTARI, 1992, p. 213). Neste sentido, consideramos que o contato com a paisagem favorece uma espécie de "visão pura" no sentido de ser compreendida enquanto contato primordial entre o sujeito poético e a paisagem. Como bem notou Gil (2009) a respeito da visão em Alberto Caeiro, e que relacionamos ao poema de Césaire, em determinados momentos de Diário de um retorno ao país natal, é como se o próprio ser da paisagem se desse a ver, independente de toda a "parafernália da subjetividade" que acompanha os sujeitos:

Em primeiro lugar, notando que a visão de Caeiro não coloca um objeto num certo lugar, diante de um sujeito; pelo contrário, o objeto só é visto numa relação "primordial" com um sujeito, mas de forma que este desapareça enquanto sujeito de uma alma ou de um interior. As coisas vistas não o são portanto pelo sujeito habitual da percepção: este encerra um eu interior que contém toda a parafernália da subjetividade - sentimentos, emoções, volições, humores. A visão de Caeiro, ao invés, supõe uma alma 'absolutamente exterior' (GIL, 2009, p. 31) 
Se existe uma paisagem afrodiaspórica no poema de Césaire, ela advém não da concepção clássica e ocidental dela, mas de uma relação fundamental em que o sujeito é uma espécie de placa sensível que é afetado intensamente por tudo aquilo que o rodeia. Tal concepção nos remete à Cézanne em sua relação fundamental com a paisagem:

[...] O artista só é um receptáculo de sensações, um cérebro, um aparelho registrador... [...] um bom aparelho, frágil, complexo, sobretudo em relação aos outros [...] o cérebro, livre, do artista, deve ser como uma placa sensível, simplesmente um aparelho registrador, no momento em que ele trabalha. [...] Mas essa placa sensível recebe banhos de sabedoria que a levam até o ponto de receptividade no qual ela pode se impregnar da imagem conscienciosa das coisas. ${ }^{5}$ (GASQUET, 2011, p. 187-191, tradução nossa).

No entanto, a nosso ver, a relação entre sujeito e paisagem, em Césaire, reportaria a outra tradição paisagística, como aquela advinda da tradição pictórica chinesa. Nas pinturas de paisagem chinesas, o sujeito se encontra comumente inserido na paisagem, representado em proporções mínimas face a grandiosidade da natureza retratada. Nessa concepção pictórica, outro tipo de perspectiva é evocado, uma dupla perspectiva em que, nas palavras de Cheng (1979), o pintor visa a criação de um espaço mediúnico onde o homem alcança a corrente vital. Mais do que um objeto a ser visto, o quadro paisagístico é para ser vivido, e esta relação entre o sujeito e o mundo implica uma zona de contaminação mútua, na qual

Nós estamos na presença de uma concepção unitária do universo que implica, entretanto, a relação interna e dialética do homem e da natureza. A natureza em sua virtualidade revela ao homem a sua própria natureza, o permitindo de se superar; e o homem ao se realizar

L'artiste n'est qu'un réceptacle de sensations, un cerveau, un appareil enregistreur... [...] un bon appareil, fragile, compliqué, surtout par rapport aux autres... [...] le cerveau, libre, de l'artiste doit être comme une plaque sensible, un appareil enregistreur simplement, au moment où il oeuvre. Mais cette plaque sensible, des bains savants l'ont amenée au point de réceptivité où elle peut s'imprégner de l'image consciencieuse des choses.

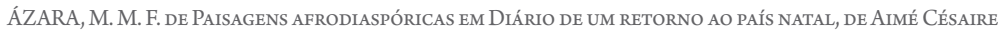


permite, por sua vez, à natureza de se realizar. [...] o homem só pode ir ao fundo de sua natureza indo ao fundo da natureza dos seres e das coisas (CHENG, 1991, p.146).

Ou ainda, em consonância com o pensamento de Besse (2009), esta outra forma de compreender a relação entre os sujeitos e a paisagem, oriunda de outros modelos paisagísticos, como o da tradição Chinesa, por exemplo, implica situá-la além do dispositivo moderno do objeto e do sujeito: "sob qual forma aparece a experiência da paisagem? Falaremos aqui de imanência, de imersão, de participação, para nomear este encontro pré-reflexivo com o inobjetivável, que constitui o núcleo do eventopaisagem.”6 (BESSE, 2009, p. 54, tradução nossa).

Dessa forma, a paisagem afrodiaspórica que emerge no texto poético do poeta martiniquenho implicaria a criação de uma zona de contaminação mútua, um devir paisagem do sujeito: "de tanto olhar as árvores tornei-me uma árvore e meus longos pés de árvore cavaram no solo largas bolsas de veneno [...] de tanto pensar no Congo/torneime um Congo farfalhante de florestas e rios." (CÉSAIRE, 2012, p. 37). Além disso, observa-se o desejo de reencontrar a potência que subjaz na natureza: " $[\mathrm{e}] \mathrm{u}$ reencontraria o segredo das grandes comunicações e das grandes combustões. Diria tempestade. Diria rio. Diria tornado. Diria folha. Diria árvore. Seria molhado por todas as chuvas, umedecido por todos os orvalhos." (CÉSAIRE, 2012, p. 27).

Entretanto, os dois trechos citados logo acima dizem respeito tanto ao desejo de regresso quanto ao efetivo regresso do sujeito poético. $\mathrm{O}$ primeiro, quando o sujeito poético já enunciara o seu regresso ao país natal, ou seja, após a marcação dêitica "e eis-me de volta" que aparece na página 27. Já o segundo trecho, remete ao momento de desejo em que o sujeito almeja regressar ao seu país natal e reencontrar o "segredo das grandes comunicações e das grandes combustões”. Caberia ressaltar

6 “[... ] sous quelle forme apparaît l'expérience du paysage ? On parlera ici d'immanence, d'immersion, de participation, pour mettre des mots sur cette rencontre préréflexive avec l'inobjectivable, qui fait le noyau de l'événement-paysage." 
também que a ilha da Martinica, que faz parte das Antilhas Francesas, é marcada por grandes cataclismos. Seja a ameaça anual dos tornados e furacões, seja o vulcão da montanha Pelée, que entrou em erupção em 1902 e arrasou a cidade de Saint-Pierre, então capital da ilha, todos esses grandes fenômenos e cataclismas que recorrentemente acometem Martinica povoam o imaginário do poeta.

Mas nos parece que a paisagem afrodiaspórica em Aimé Césaire, em um primeiro momento e apesar da relação fundamental com a natureza, não apresenta a comunhão total com os elementos da terra, tal como ocorre, por exemplo, na tradição pictórica chinesa. O devir paisagem do sujeito poético, ocorrido no instante do reencontro com a terra natal, nos parece ser um momento ideal da paisagem afrodiásporica. No entanto, principalmente na primeira parte do poema, a relação entre afetar e ser afetado pela paisagem se dá de maneira conflituosa. Existe uma força "putrefadora" na hora incerta do crepúsculo, e não uma relação harmoniosa:

No fim da madrugada...[...] eu nutria o vento, soltava os monstros e ouvia subir para além do desastre um rio de rolinhas e de trevos da savana que carrego sempre nas minhas profundezas a uma altura inversa à do vigésimo andar dos edifícios mais insolentes e por precaução contra a força putrefadora dos ambientes crepusculares, varrida noite e dia por um maldito sol venéreo. (CÉSAIRE, 2012, p. 9)

A utilização de termos relacionados a enfermidades, as descrições negativas e a visão de uma cidade em ruínas desvelam o mal-estar causado por este primeiro olhar em direção à ilha: "cantamos as flores venenosas explodindo nas pradarias furibundas; os céus de amor cortados de embolia; as manhãs epilépticas; o branco abrasar das areias abissais; o afundar nas noites fulminadas de feros odores." (p. 43). Tal olhar desnuda a condição colonial e miserável das Antilhas Francesas, antes da mudança de estatuto de colônia para território ultramarino Francês, o que ocorrerá em 1946. Neste contexto, a visão do poeta é a de uma terra em ruínas, em estado de decomposição "no fim da madrugada, florescentes de enseadas 
tenras, as Antilhas que têm fome, as Antilhas marcadas pela varíola, as Antilhas dinamitadas pelo álcool, encalhadas na lama dessa baía, na poeira dessa cidade sinistramente encalhadas." (CÉSAIRE, 2012, p. 9). Apesar do incômodo dessas descrições paisagísticas, a relação fundamental que liga o sujeito à paisagem de maneira pré-racional, pré-lógica e sensível ainda está presente: “[...] eu voltaria liso e jovem a este país meu e diria a este país cujo limo entra na composição da minha carne: 'Andei por muito tempo errante e volto para a hediondez desertada das vossas chagas.” (p.29). A paisagem entra na composição da carne do sujeito poético. Ao atravessar e ser atravessado por ela, a relação já não se fundamenta como aquela dada pela perspectiva clássica, que pressupunha o distanciamento do contemplador. O contato primevo com o mundo é antes de mais nada da ordem do sensível, das sensações, dos perceptos e afetos que se inscrevem, se imprimem no sujeito. Como no relato do conterrâneo de Césaire, o escritor Édouard Glissant, a paisagem martiniquenha parece possuir este poder de afetação naqueles que a atravessam, haja vista a grandiosidade dos seus fenômenos naturais e cataclismas e a exuberância da sua flora, fauna e geologia:

Eu conto às vezes que quando eu tinha talvez um mês de existência, minha mãe me pegou pelos braços e atravessou a Martinica em diagonal para ir de Sainte-Marie, onde eu nasci, até o Lamentin, onde eu cresci. E eu estou absolutamente persuadido que me lembro desta viagem. Que há qualquer coisa que restou. Que a paisagem, e a paisagem martiniquenha foi impressa em mim, naquele momento, de uma maneira definitiva, qualquer coisa que cresceu e me comoveu durante toda a minha existência. ${ }^{7}$ (GLISSANT, 2005b, on-line, tradução nossa).

A experiência da paisagem, mesmo pelo viés do mal-estar, ainda se configura através da relação fundamental entre o homem e a natureza,

Je raconte parfois que quand j'avais peut-être un mois d'existence, ma mère m'a pris sous le bras et a traversé la Martinique en diagonale pour aller de Sainte-Marie où je suis né, au Lamentin, où j’ai grandi. Et, je suis absolument persuadé que je me souviens de ce voyage-là. Qu'il y a quelque chose qui est restée. Que le paysage, et le paysage martiniquais a imprimé en moi, là, d'une manière définitive, quelque chose qui a grandi et qui a bougé au fur et à mesure de mon existence. 
como aquilo que Collot (2011) nomeara de um "pensamento-paisagem", em que a paisagem dá a pensar, suscita o pensamento, e o pensamento se desdobra como paisagem, remete à antiga aliança entre o homem e o seu ambiente, e se incrusta nas palavras, na experiência poética : "porque a literatura produz uma forma específica de pensamento que, a partir da experiência da paisagem, se inscreve nas qualidades sensíveis da linguagem." (COLLOT, 2011, p. 14). Mas se para o pensador francês o fundamental da paisagem ainda residia no fato de ela ser dependente de uma subjetividade que visa apreender a paisagem, ou seja, ela é dada enquanto produto do encontro entre o mundo e um ponto de vista (COLLOT, 2011), na experiência narrada por Glissant, e também no trecho citado anteriormente do poema de Césaire, a paisagem, como na perspectiva apontada por Besse (2009, p.50), é algo da ordem de um evento, do encontro concreto entre o homem e o mundo que o rodeia. No entanto, esta relação entre o homem e o mundo, em que o sujeito afeta e é afetado, só desponta algumas vezes no poema, principalmente após a efetivação do regresso à terra natal. Antes da volta, as descrições da paisagem são de uma terra arrasada, infértil e fétida:

Uma miséria também essa praia, com montes de lixo apodrecendo, traseiros furtivos que aí defecam, e a areia é preta, fúnebre, nunca se viu uma areia tão preta, e a espuma desliza ganindo sobre ela, e o mar a golpeia com grandes murros de boxe, ou melhor, o mar é um enorme cão que lambe e morde a praia nos tornozelos, e de tanto mordê-la acabará, na certa, por devorá-la, a praia e a rua palha com ela. (CÉSAIRE, 2012, p. 25).

O amargor com relação à paisagem desvela a crítica feroz que o poeta dirige ao sistema colonial, tal como aparece em seu Discurso sobre o colonialismo (1955): “[...] a chamada civilização "europeia”, civilização "ocidental”, tal como foi moldada por dois séculos do governo burguês, é incapaz de resolver os dois problemas aos quais a sua existência deu origem: o problema do proletariado e o problema colonial; [...] a Europa é indefensável." (CÉSAIRE, 1955, p. 13). Em determinados momentos 
do poema, é como se o próprio ser da paisagem se desse a ver, além das projeções, inquietações e desgostos do poeta. A hora crepuscular que permeia o início do poema como um refrão, propícia ao percepto, é como se o próprio morro, por exemplo, surgisse no poema, independente do estado mental do sujeito poético:

No fim da madrugada, o morro esquecido, esquecendo-se de explodir/No fim da madrugada, o morro de casco inquieto e dócil - seu sangue impaludado derrota o sol com seu pulsar febril/No fim da madrugada, o incêndio contido do morro, como um soluço amordaçado à beira da explosão sanguinária, em busca de uma ignição que se esquiva e se desconhece/No fim da madrugada, o morro agachado diante da bulimia à espreita de raios e de moinhos, lentamente vomitando suas fadigas de homens, o morro só e seu sangue derramado, o morro e seus pensos de sombra, o morro e suas valetas de medo, o morro e suas grandes mão de vento (CÉSAIRE, 2012, p.13).

Além daquela crítica ao colonialismo, ressaltamos também que o poeta, espécie de "Orfeu negro", para lembrar o clássico e fundamental ensaio de Sartre (1968), desce às profundezas de si mesmo, às profundezas da sua terra natal para dali emergir e fazer vir à tona o termo negritude. Dessa forma, remetemos mais uma vez àquele primeiro momento da razão negra, àquela primeira cisão provocada pelo tráfico transatlântico. Tal cisão provocou a dispersão de milhares de etnias africanas nas Américas, e configurou a primeira desterritorialização dos sujeitos escravizados. Os primeiros deportados foram apartados da terra primeva e "transformados em homens-objeto, homens-mercadoria e homens-moeda." (MBEMBE, 2019 , p. 14). Já no segundo momento da razão negra, quando escrita e pensamento começaram a ser elaborados, aquela primeira cisão inicial ainda é sentida, através do preconceito, da discriminação racial, e também pela falta de oportunidade que legou aos negros o estado permanente de desabrigo. Dessa forma, o sujeito poético, alienado de si mesmo, desce às profundezas da sua terra natal, ao inferno de si mesmo, para tomar consciência do estado de alienação do sujeito em diáspora: “[...] e o negro 
cada dia mais baixo, mais covarde, mais estéril, menos profundo, mais disperso, mais separado de si mesmo, mais sonso consigo mesmo, menos imediato consigo mesmo." (CÉSAIRE, 2012, p.79). E é neste sentido também que afirmamos haver uma espécie de poética do desabrigo que insufla diversas manifestações culturais afrodiaspóricas e que pretendemos desenvolver em um outro momento. A desterritorialização ou dépaysement (expressão francesa para a perda de referências advinda da mudança de país, de lugar, de vida, mas que também se refere às novas possibilidades surgidas com a mudança) parece ser uma condição fundamental para a compreensão de diversas obras que tratam da Diáspora Negra, tal como em Diário de um retorno ao país natal.

A negritude, como bem pontuou Bernd (1988, p. 20), diz respeito, em um sentido mais amplo, à "tomada de consciência de uma situação de dominação e discriminação, e a consequente reação pela busca de uma identidade negra”. Assim sendo, após a descida abissal e a tomada de consciência, o sujeito poético começa a compreender a natureza, a paisagem, e todos aqueles fenômenos naturais que assolam a pequena ilha enquanto força, potência e devir do ato de forjar uma nova subjetividade, novas identidades dadas pela negritude:

E eis que de repente força e vida me assaltam como um touro e a onda da vida circunda a papila do morto, eis que todas as veias e venículas de apressam ao sangue novo e o enorme pulmão dos ciclones respira e eis o fogo tesaurizado dos vulcões e o gigantesco pulso sísmico batendo agora o compasso e um corpo vivo no meu firme abrasar./ E estamos de pé agora, meu país e eu, os cabelos ao vento, minha mão pequena agora no seu punho enorme e a força não está em nós, mas acima de nós, numa voz que verruma a noite e a audiência como a penetrância de uma vespa apocalíptica. E a voz proclama que a Europa durante séculos nos cevou de mentiras e inchou de pestilências,/ porque não é verdade que a obra do mundo está acabada/ que não temos nada a fazer no mundo (CÉSAIRE, 2012, p.79).

Surge então, com a cristalização do termo negritude, a potência e força, antes putrefadoras, agora propulsoras de um novo sujeito porvir. 
Tanto o país quanto o sujeito se encontram de pé, erguidos, e o primeiro, apto a denunciar todas as mazelas legadas pelo colonialismo. Assim, todo aquele mal-estar causado em um primeiro momento, cede lugar à possibilidade de comunhão entre o sujeito e a natureza:

A terra/ silo onde se preserva e amadurece o que a terra tem de mais terra/ minha negritude não é uma pedra, sua surdez lançada contra o clamor do dia/ minha negritude não é uma mancha de água morta sobre o olho/ morto da terra/ minha negritude não é uma torre nem uma catedral/ ela mergulha na carne rubra do solo/ela mergulha na carne ardente do céu/ ela perfura o abatimento opaco com a sua reta paciência (CÉSAIRE, 2012, p.65).

A negritude não é uma torre nem uma catedral, não é nenhum monumento erguido pelo Ocidente, mas sim um mergulho na carne do solo, do céu e, em determinados momentos, um mergulho na paisagem.

\section{Conclusão}

O que é meu, esses vários milhares de mortiferados que giram em torno da cabaça de uma ilha, e o que é meu também, o arquipélago arqueado como o desejo inquieto de negar-se, dir-se-ia uma ânsia materna de proteger a tenuidade tão delicada que separa uma da outra América; e seus flancos que destilam para a Europa o bom licor de um Gulf Stream, e uma das duas vertentes de incandescências entre as quais o Equador funambula em direção à África. E minha ilha não-fechada, sua clara audácia de pé na popa dessa polinésia diante dela, Guadalupe fendida em duas por sua linha dorsal e de igual miséria à nossa, Haiti onde a negritude se pôs de pé pela primeira vez e disse que acreditava na sua humanidade e a cômica pequena cauda da Flórida onde de um negro se consuma o estrangulamento e a África gigantescamente arrastando-se até o pé hispânico da Europa, sua nudez em que a Morte ceifa com movimentos largos. (CÉSAIRE, 2012, p. 31)

A negritude vem à tona no poema após uma laboriosa e necessária descida às profundezas do próprio sujeito e da paisagem natal. Tanto no 
movimento declinante quanto no movimento de ascensão, a paisagem, de certa forma redentora, acompanha a travessia do sujeito poético. Partimos do pressuposto que, no primeiro momento da razão negra, a paisagem constituía um interdito, o direito de olhar as coisas era negado. Já no segundo momento, que culmina com os diversos discursos, relatos e movimentos como o da negritude, o do Harlem Renaissance, do negrismo cubano e do indigenismo haitiano, os sujeitos, em diáspora ou em exílio, passam a poder expressar não só a aceitação da condição negra, mas a revolta, o orgulho, a negritude. O olhar do poeta é marcado por uma solidariedade transnacional que abarca portos, países, plantações por onde transitaram e continuam transitando os sujeitos da Diáspora Negra:

E eu me digo Bordéus e Nantes e Liverpool/ e Nova York e São Francisco/ não há nem um pedaço desse mundo que não tenha minha impressão digital/ e meu calcâneo sobre o dorso dos arranha-céus e minha sujeira/no cintilar das gemas!/ Quem pode gabar-se de ter mais do que eu?/ Virgínia. Tennesse. Geórgia. Alabama./ Putrefações monstruosas revoltas inoperantes,/ pântanos pútridos de sangue/ trombetas absurdamente abafadas/ Terras rubras, terras sanguíneas, terras consanguíneas. (CÉSAIRE, 2012, p. 33).

Salientamos que a configuração das paisagens afrodiaspóricas em Diário de um retorno ao país natal implica em uma quebra do paradigma clássico de concepção paisagística dado pela perspectiva moderna. O sujeito poético, inicialmente na França metropolitana, e posteriormente na sua terra natal, apresenta um olhar rizomático, múltiplo e aberto, que engloba a história da Diáspora Negra, os fluxos e trânsitos entre os continentes que subsumem, por sua vez, aquilo que Gilroy (2001) nomeara de o "Atlântico Negro", memórias, ancestralidades e sincretismos.

Por fim, esse olhar rizomático que percorre paisagens, elementos, sensações, visões e memórias na poesia de Césaire, talvez se assemelharia àquela contraposição entre a observação a partir de uma bicicleta e a observação desde um helicóptero, tal como propôs o poeta português Herberto Helder: 
Declaram que a melhor maneira de contemplar a natureza é de cima de uma bicicleta (Marilyn Monroe dixit); talvez a forma eleitamente apocalíptica e luminosa de escrutar a poesia seja de helicóptero. Não se pense que a passagem da bicicleta ao helicóptero seja apenas uma subida de graus, é decerto uma alteração de categorias. Desde que se assegurou aristotelicamente a arte imitar a natureza, a natureza começou a desavir-se dentro da arte; e então a arte obrigou-se à expulsão da natureza, para ter a casa na sua ordem, e nela manter habitação, sono e insônia próprios, e o despertar e a vida seguida. Conforme informações britânicas, a natureza pôs-se então a imitar a arte, coisa de algum regozijo irônico para ela, que se fez cada vez mais imaginosa, a ver até onde a natureza obtinha astúcias e recursos plagiários. Foi depois do conflito que a bicicleta se prestou às inquirições naturais. Portanto, a bicicleta passou a ser instrumento de observação da natureza, uma peça laboratorial das ciências naturais. Como a arte não era parte nisso, teve a subtileza de mobilizar a movimentação para os aeroportos helicopterianos. Veja-se que argutamente substituía, à visão horizontal dos interessados na natureza, a visão vertical - abissal - dos seus próprios panoramas, móveis (assim) em todos os sentidos e direções, e até imóveis (para os casos obsessivos), quando o helicóptero estaca atentamente no ar, seduzido por particularidades ou generalidades do território poético, também dito texto, escrita ou discurso, conforme conveniências geográficas de dicção. (HELDER, 1979, p. 60-61).

$\mathrm{Na}$ concepção do poeta português a respeito da contemplação da natureza, à visão horizontal, tal como ocorre na perspectiva clássica, seria necessário contrapor a visão vertical e abissal do helicóptero, que açambarca vários sentidos e direções. Este olhar rizomático, múltiplo e aberto, diz respeito ao engendramento de uma poética do desabrigo, do desterro e da desterritorialização que acompanha algumas manifestações culturais e artísticas da Diáspora Negra.

Apesar do desenraizamento inicial que, a nosso ver, é importante para compreendermos a estética afrodiaspórica, seria necessário salientar também que o que Glissant nomeara de pensamento do rastro/resíduo diz respeito, antes de mais nada, ao pensamento Africano pré-colonial. Se, 
como afirmou Hall (2003, p. 27), "na situação da diáspora, as identidades tornam-se múltiplas”, tal multiplicidade também é composta pela presença de formas residuais, pré-coloniais, de pensamentos, costumes, culturas e modos de vida. Dessa forma, se é possível falar em paisagem afrodiaspórica, é porque, além do desenraizamento, ela presentifica também uma relação fundamental do sujeito com o seu ambiente. Como bem notou Mbembe (2019), a importância das redes e encruzilhadas na literatura africana atestam a importância daquilo que o mundo ocidental nomeara de Animismo, mas que diz respeito a uma concepção de mundo dinâmica, pautada pelo movimento e pela abolição de fronteiras, em que os diversos entes vivem em mútua interação:

As encruzilhadas, os fluxos de pessoas e os fluxos da natureza, ambos em relações dialéticas, porque nessas cosmogonias as pessoas são impensáveis sem o que chamamos de natureza. [...]Porque não se pode pensar nas pessoas sem pensar nos não humanos. Leia Tutuola, é um mundo de humanos e não humanos interagindo, agindo uns com os outros. (MBEMBE, 2019, on-line).

Neste sentido, um estudo mais detalhado e amplo das configurações das paisagens afrodiaspóricas na literatura envolve também uma análise mais precisa das diversas cosmovisões que englobam o pensamento africano pré-colonial, em suas diversas matizes étnico-geográficas que moldam o imaginário estético da Diáspora Negra. Por fim, finalizamos este estudo demonstrando que o olhar rizomático do sujeito poético, em seu processo de afirmação da negritude, se volta também às virtudes ancestrais, ao momento de contato primordial do sujeito com o mundo, tal como era compreendida esta relação - humano/natureza - na África pré-colonial:

Verdadeiramente os filhos primogênitos do mundo/porosos a todos os sopros do mundo/eira fraterna de todos os sopros do mundo/leito sem dreno de todas as águas do mundo/fagulha do fogo sagrado do mundo/carne da carne do mundo palpitando com o próprio/movimento do mundo/Tépida madrugada de virtudes ancestrais $[. .$.$] a$ 
exaltação reconciliada do antílope e da estrela/ aqueles cuja sobrevivência caminha na germinação da erva! Eia perfeito círculo do mundo e fechada concordância! (CÉSAIRE, 2012, p. 65-67).

Aphrodiasporic landsCapes in Notebook of a RetUrn to the Native LAND BY AIMÉ CÉSAIRE

\section{Abstract}

The purpose of this article is to investigate in Aphrodiasporic landscapes in Notebook of a Return to the Native Land by Aimé Césaire (1939), a fundamental poem by the Martinican poet Aimé Césaire, the configuration of the Aphrodiasporic landscapes. The long poem, written in free verse poems, is one of the milestones of the political, aesthetic, cultural and ideological movement of Negritude, launched in Paris in the 1930s, but which brings together in its core various cultural manifestations of the Black Diaspora, such as the Harlem Renaissance, emerged in the United States in the 1920s, the Indigenism of Haitian literature, of the same decade, and Cuban Negrismo of the 1930s.

Keywords: Négritude. Aimé Césaire. Black Diaspora. Landscapes. Poetics of homelessness.

Paisajes afrodiaspóricos en el Retorno al país natal, de Aimé CÉSAIRE

\section{RESUMEN}

El propósito de este artículo es indagar en Retorno al país natal (1939), poema fundamental del poeta de la Martinica Aimé Césaire, la configuración de los paisajes Afrodiaspóricos. El largo poema, escrito en versos libres, es uno de los hitos del movimiento político, estético, cultural e ideológico de Negritud, lanzado en París en la década de 1930, pero que reúne en su núcleo diversas manifestaciones culturales de la Diáspora Negra, como el Renacimiento de Harlem, surgido en Estados Unidos en los años veinte, el indigenismo de la literatura haitiana, de la misma década, y el Negrismo cubano de los años treinta.

Palabras clave: Negritud. Aimé Césaire. Diáspora negra. Paisaje. Poética del desamparo. 


\section{REFERÊNCIAS}

AZARA, Michel Mingote Ferreira de. Paisagem e perambulação urbana: Samuel Rawet em diálogo com as artes visuais. 2015. 250 f. Tese (Doutorado em Teoria da Literatura e Literatura Comparada) - Faculdade de Letras, Universidade Federal de Minas Gerais, Belo Horizonte, 2015.

BERND, Zilá. O que é negritude. São Paulo: Brasiliense,1988.

BESSE, Jean-Marc. Ver a terra: seis ensaios sobre a paisagem e a geografia. São Paulo: Perspectiva, 2006.

BESSE, Jean-Marc. Le Goût du monde : exercices de paysage. Arles: Actes Sud; École Nationale Supérieure du Paysage, 2009.

CÉSAIRE, Aimé. Diário de um retorno ao país natal. Tradução Lilian Pestre de Almeida. Sâo Paulo: Edusp, 2012.

CÉSAIRE, Aimé. Discurso sobre o colonialismo. São Paulo: Editora Veneta, 1955. CHENG, François. Vide et plan: Le langage pictural chinois. Paris: Éditions du Seuil, 1979.

COLLOT, Michel. La Pensée-paysage. Arles: Actes Sud; École Nationale Supérieure du Paysage, 2011.

DELEUZE, Gilles; GUATTARI, Félix. O que é a Filosofia? Tradução Bento Prado Júnior e Alberto Alonso Muñoz. São Paulo: Editora 34, 1992. (Coleção Trans).

FERRARA, Lucrécia D’Alésio. Olhar periférico: informação, linguagem, percepção ambiental. São Paulo: EDUSP, 1993.

GASQUET, Joaquim. Ce qu'il m’a dit..., extrait de Cézanne. In: DORAN, Michael (Org.). Conversations avec Cézanne. Paris: Macula, 2011.

GIL, José. Diferença e negação na poesia de Fernando Pessoa. Rio de Janeiro: Relume-Dumará; Sinergia; Ediouro, 2009.

GILROY, Paul. O Atlântico Negro: modernidade e dupla consciência. São Paulo: Ed. 34; Rio de Janeiro: Universidade Cândido Mendes, Centro de Estudos AfroAsiáticos, 2001.

GLISSANT, Édouard. Introdução a uma poética da diversidade. Juiz de Fora: Editora UFJF, 2005a. 
GLISSANT, Édouard. Émission Invitation au voyage : Magazine présenté par Laure Adler, 14 février 2005b sur TV5. Disponível em: http://www.potomitan. info/atelier/glissant3.php Acesso em: 25 fev. 2021.

GLISSANT, Édouard. Poética da relação. Rio de Janeiro: Sextante Editora, 2011. Disponível em: http://artafrica.letras.ulisboa.pt/uploads/ docs/2016/04/11/570bc0a278725.pdf Acesso em: 09 fev. 2011.

HALL, Stuart. Pensando a diáspora: reflexões sobre a terra no exterior. In: SOVIK, Liv (org.). Da diáspora: identidades e mediações culturais. Tradução Adelaine La Guardia Resende. Belo Horizonte: Editora UFMG; Brasília: Representação da Unesco no Brasil, 2003.

HELDER, Herberto. Photomaton \& Vox. Lisboa: Assírio e Alvim, 1979.

MBEMBE, Achille. A crítica da razão negra. Lisboa: Antígona, 2014.

JAKOB, Michael. Le Paysage. Gollion (Suíça): Infólio, 2013.

MBEMBE, Achille. Afropolitanismo. Tradução Cleber Daniel Lambert da Silva. Áskesis. Revista dos Discentes do Programa de Pós-Graduação em Sociologia da UFSCar, v. 4, n. 2, p. 68-71, jul./dez. 2015.

MBEMBE, A. A ideia de um mundo sem fronteiras. Revista Serrote, São Paulo, n. 31. mar. 2019.

MORTARI, Cláudia (org.). Introdução aos estudos africanos e da diáspora. Florianópolis: IOESC, 2015.

MOURA, Clóvis. A quilombagem como expressão de protesto radical. 2019. Disponível em: https://movimentorevista.com.br/2019/11/a-quilombagemcomo-expressao-de-protesto-radical/. Acesso em: 01 fev. 2021.

PEREIRA, Edimilson de Almeida. Homeless. Belo Horizonte, Mazza, 2010.

SARTRE, Jean-Paul. Orfeu Negro. In: SARTRE, Jean-Paul. Reflexões sobre o racismo. Tradução J. Guinsburg. 5. ed. São Paulo: Difel, 1968.

SÜSSEKIND, Flora. O Brasil não é longe daqui. São Paulo: Companhia das Letras, 2000.

Submetido em 05 de março de 2021

Aceito em 10 de abril de 2021

Publicado em 30 de maio de 2021 